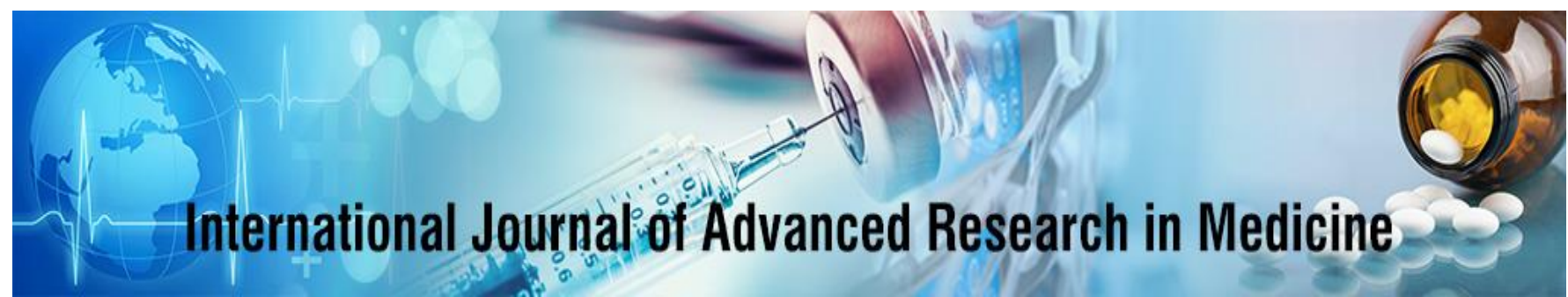

E-ISSN: 2706-9575

P-ISSN: 2706-9567

IJARM 2020; 2(2): 114-119

Received: 26-05-2020

Accepted: 29-06-2020

Dr. Bodepudi Sarath

Assistant Professor,

Department of Psychiatry,

Pinnamaneni Siddhartha

Institute of Medical Sciences \&

Research Foundation,

Chinavutapalli, Vijayawada,

Andhra Pradesh, India.

Dr. Chodagiri Vamsi Krishna Assistant Professor,

Department of Psychiatry,

Siddhartha Medical College,

Vijayawada, Andhra Pradesh, India.

Dr. Kamuju Narsimhareddy Professor, Department of Psychiatry, Maharaja Institute of Medical Sciences, Vizianagaram, Andhra Pradesh, India.
Corresponding Author: Dr. Chodagiri Vamsi Krishna Assistant Professor, Department of Psychiatry, Siddhartha Medical College, Vijayawada, Andhra Pradesh, India.

\section{A study on the prevalence and type of tobacco use among students in Visakhapatnam sub metropolitan city}

\author{
Dr. Bodepudi Sarath, Dr. Chodagiri Vamsi Krishna and Dr. Kamuju \\ Narsimhareddy
}

DOI: https://doi.org/10.22271/27069567.2020.v2.i2b.57

\begin{abstract}
Background: Adolescence is an important phase of development in life. Tobacco use is more prevalent among adolescents and several factors influence their decisions to initiate at that age.

Aim \& Objectives: This study aims to determine the magnitude of tobacco use (both smoked and smokeless tobacco products) among adolescent high-school students in Visakhapatnam, sub metropolitan city in Andhra Pradesh.

Methodology: This is a school-based cross-sectional descriptive study. The study is based on framework of the Global Youth Tobacco Survey (GYTS) designed and conducted by the World Health Organization (WHO) and Centers for Disease Control (CDC).

Results: In the present study, there is a statistically significant association between the tobacco use and the adolescent students in the private and government schools. Tobacco is being used in multiple forms; few of which are in the smoking forms as cigarettes and bidis and also in the form of chewing tobacco as gutka or zarda. The other form in which tobacco is being used is in the form of Mishri and also as a toothpaste and toothpowder. Tobacco initiation started at a very early age (7 years). Initiation of tobacco use was higher in the younger age group (8-10 years) and percentage of adolescents initiating tobacco use decreased as the age increased. There is no difference in the attitude with regards to attractiveness of the boys who smoke in both Private and Government school.

Conclusion: Finally we Adolescent students from both Government and Private schools feel that girls look less attractive if they smoke. Most students feel that students who use tobacco have fewer friends than when compared to the students who do not smoke.
\end{abstract}

Keywords: tobacco, smoking, gutka, adolescents, government, private

\section{Introduction}

Tobacco is most commonly used as a recreational drug consumed in the forms of smoking, chewing, snuffing, or dipping. Tobacco is an agricultural product processed from the leaves of plants in the genus Nicotina. Nicotine is the main alkaloid present in tobacco leaves. Because of the addictive properties of nicotine, tolerance and dependence develop. ${ }^{[1]}$

The usage of tobacco is an activity that is practiced by 1.1 billion people, and up to $1 / 3^{\text {rd }}$ of the adult population. The World Health Organization (WHO) reports it to be the leading preventable cause of death worldwide and estimates that it currently causes 5.4 million deaths per year ${ }^{[1]}$.

The Global Youth Tobacco Survey (GYTS) conducted in 131 countries, in which 750,000 students of ages 13-15 years were tobacco users, it was found that approximately $9 \%$ of students were current smokers while $11 \%$ currently used tobacco products other than cigarettes ${ }^{[2]}$. India is the second largest consumer of tobacco in the world, after China

Both smoking and non smoking forms of tobacco use are common in India. Reports of tobacco use in different population groups states its prevalence as $15 \%$ to $50 \%$ among men. According to WHO estimates, in India about 194 million men and 45 million women use tobacco in smoked or smokeless form ${ }^{[3]}$.

In India, tobacco use among children and youth is quite high compared to other countries. The Global Youth Tobacco Survey (GYTS) 2006 reveals that the prevalence of current use of tobacco among 13-15-year-olds is $14 \%$. Studies among students across the Indian 
metropolises provide variable estimates of the current use of tobacco from as low as $4 \%$ in Mumbai to as high as $41.1 \%$ in Chennai ${ }^{[4]}$.

Cigarette Smoking is one of the worst habits that is being followed by the majority of the world population. This is an addiction which silently kills body organs and leaves you with serious illness and other diseases which may lead to death ${ }^{[5]}$.

Adolescence is an important phase of development in life. Tobacco use is more prevalent among adolescents and several factors influence their decisions to initiate at that age. This study is supported to prove that the magnitude of tobacco use is very high and several factors contribute to the initiation of tobacco use during adolescence.

This study aims to determine the magnitude of tobacco use (both smoked and smokeless tobacco products) among adolescent high-school students in Visakhapatnam, sub metropolitan city in Andhra Pradesh.

\section{Material and Methods \\ Research Design}

This is a school-based cross-sectional descriptive study.

The study is based on framework of the Global Youth Tobacco Survey (GYTS) designed and conducted by the World Health Organization (WHO) and Centers for Disease Control (CDC).

\section{Tools used}

1. Global Youth Tobacco Survey (GYTS) Questionnaire.

\section{Study population}

The study population is the adolescent students of grade 8, 9 and 10 from secondary schools within Visakhapatnam sub metropolitan city.

\section{Sampling}

Schools with at least 100 secondary students (in grades 8, 9 and 10) are selected for the study.

Eligible schools are stratified into governmental and nongovernmental categories.

\section{Sample size}

Sample size of the present study is 620 .

\section{Sampling technique}

Simple random sample

Students absent on the day of the survey are excluded from the study.

\section{Tools for data collection}

\section{Section: A}

The study is based on framework of the Global Youth Tobacco Survey (GYTS) designed and conducted by the
World Health Organization (WHO) and Centers for Disease Control (CDC).

Data is collected by GYTS questionnaire.

\section{Data collection procedure}

Students who met the inclusion criteria are recruited from the schools after obtaining written informed consent.

The present study is conducted through the following phases;

Phase I-Questionnaire is completed by the students and are evaluated based on the questionnaire.

\section{Phase II -Data Analysis}

Data is coded and entered in the computer using excel. Statistical analysis is done using Statistical Package for the Social Sciences (SPSS).

\section{Phase III- Report Writing}

A report of the entire research process, including analysis of the results and discussion is compiled.

\section{Results}

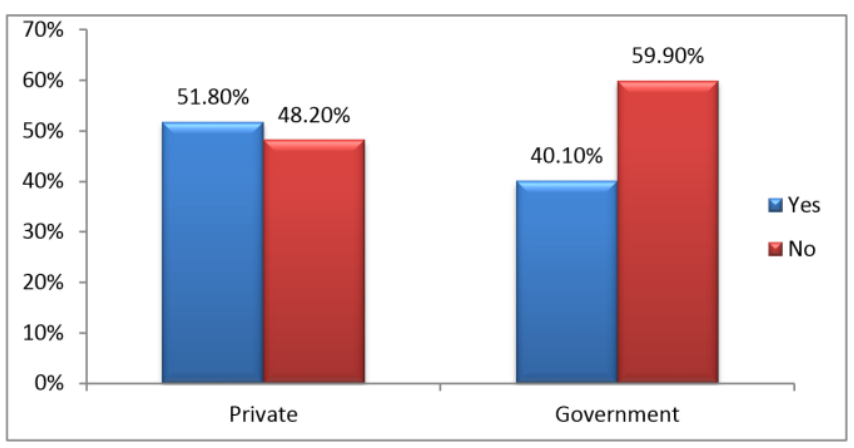

Fig 1: Comparison of Prevalence of tobacco use among adolescent students in government and private school students

$51.8 \%$ of the students were using tobacco in Private school as compared to $40.1 \%$ of the students in Government school. $48.2 \%$ of the students were not using tobacco in Private school as compared to $59.9 \%$ of the students in Government school. There is a higher use of tobacco in students of private schools than when compared with students of government schools.

$66.9 \%$ of the males were using tobacco products and $33.1 \%$ of the females are using tobacco products in the study. There is more percentage of males using tobacco products in private school $(97.7 \%)$ and there is a higher percentage of tobacco use among females in government school $(62.5 \%)$.

Table 1: Comparison of age of initiation of tobacco use between adolescent students of Private and Government school

\begin{tabular}{|c|c|c|c|c|}
\hline & & \multicolumn{2}{|c|}{ Type of School } & \multirow{2}{*}{ Total } \\
\hline & & Private & Government & \\
\hline \multirow{7}{*}{ How old were you when you first tried tobacco in any form? } & I have never tried any tobacco & $51.8 \%$ & $59.9 \%$ & $56.0 \%$ \\
\hline & 7 years old or younger & $5.6 \%$ & $10.1 \%$ & $7.9 \%$ \\
\hline & 8 or 9 years old & $18.8 \%$ & $2.2 \%$ & $10.3 \%$ \\
\hline & 10 or 11 years old & $3.6 \%$ & $15.5 \%$ & $9.7 \%$ \\
\hline & 12 or 13 years old & $11.9 \%$ & $8.2 \%$ & $10.0 \%$ \\
\hline & 14 or 15 years old & & $4.1 \%$ & $2.1 \%$ \\
\hline & 16 years old or older. & $8.3 \%$ & & $4.0 \%$ \\
\hline \multicolumn{2}{|l|}{ Total } & $100.0 \%$ & $100.0 \%$ & $100.0 \%$ \\
\hline
\end{tabular}


$56 \%$ of the students have never tried tobacco in any form. $10.3 \%$ of the students are 8-9 years old when they first tried tobacco and $10 \%$ of the students are 12-13 years old when they tried tobacco followed by students of 10-11 years old. Tobacco use by close friends and family members were strong influencing factors for tobacco use of adolescent students. A substantial proportion of adolescent students are being exposed to the tobacco use behaviour of family members and friends, creating an environment to develop more tobacco users in the future.

Table 2: Comparison of patterns of tobacco use between private and government school adolescent students

\begin{tabular}{|c|c|c|c|c|}
\hline \multicolumn{2}{|c|}{} & \multicolumn{2}{|c|}{ Type of School } & \multirow{2}{*}{ Total } \\
\cline { 3 - 5 } \multicolumn{2}{|c|}{ Private } & Government & \\
\hline \multirow{3}{*}{ During the past 30 days, did you smoke tobacco in any form? } & I did not smoke tobacco in any form & $70.6 \%$ & $84.9 \%$ & $77.9 \%$ \\
\cline { 2 - 5 } & I mainly smoked bidis & $5.0 \%$ & & $2.4 \%$ \\
\cline { 2 - 5 } & I mainly smoked cigarettes. & $5.6 \%$ & & $2.7 \%$ \\
\cline { 2 - 5 } & I smoked tobacco in other forms. & $16.5 \%$ & $11.0 \%$ & $13.7 \%$ \\
\cline { 2 - 5 } & I smoked tobacco in multiple forms. & $2.3 \%$ & $4.1 \%$ & $3.2 \%$ \\
\hline \multicolumn{2}{|c|}{ Total } & $100.0 \%$ & $100.0 \%$ & $100.0 \%$ \\
\hline
\end{tabular}

$70.6 \%$ and 84.90 of the students did not smoke tobacco in any form in private school and government schools respectively. Maximum number of students smoked tobacco in other forms.16.5\% and $11 \%$ of the students smoked tobacco in other forms in private and government schools respectively. Tobacco is also smoked as bidis and cigarettes in private schools but not in government schools. Tobacco is smoked in multiple forms more in government schools $(4.1 \%)$ than private schools $(2.3 \%)$.

Table 3: Comparison of methods of obtaining tobacco/tobacco products between private and government school adolescent students in the past 30days

\begin{tabular}{|c|c|c|c|c|}
\hline & & \multicolumn{2}{|c|}{ Type of School } & \multirow{2}{*}{ Total } \\
\hline & & Private & Government & \\
\hline \multirow{8}{*}{$\begin{array}{l}\text { During the past } 30 \text { days (one month), how did you } \\
\text { usually get your bidi, cigarette or other tobacco? }\end{array}$} & $\begin{array}{l}\text { I did not smoke or use any tobacco during } \\
\text { the past } 30 \text { days (one month) }\end{array}$ & $70.6 \%$ & $77.3 \%$ & $74.0 \%$ \\
\hline & $\begin{array}{l}\text { I bought them in a store, shop or from a } \\
\text { street vendor. }\end{array}$ & $8.6 \%$ & $12.9 \%$ & $10.8 \%$ \\
\hline & It was available at home & $4.3 \%$ & $6.9 \%$ & $5.6 \%$ \\
\hline & $\begin{array}{l}\text { I gave someone else money to buy them } \\
\text { for me }\end{array}$ & $1.0 \%$ & & $.5 \%$ \\
\hline & I borrowed them from someone else & $8.3 \%$ & & $4.0 \%$ \\
\hline & I picked it from somewhere & & $2.8 \%$ & $1.5 \%$ \\
\hline & An older person gave them to me & $1.7 \%$ & & $.8 \%$ \\
\hline & I got them in some other way & $5.6 \%$ & & $2.7 \%$ \\
\hline \multicolumn{2}{|l|}{ Total } & $100.0 \%$ & $100.0 \%$ & $100.0 \%$ \\
\hline
\end{tabular}

$70.6 \%$ of the students from private school and $77.30 \%$ of the students from government school did not use any tobacco product during the past 30 days. $8.60 \%$ of the students from private school and $12.90 \%$ of the students from government school bought cigarette/tobacco products from a street vendor. $8.30 \%$ of the students from private school borrowed them from someone else.

Table 4: Comparison of number of cigarettes smoked between private and government school adolescent students in the past 30 days.

\begin{tabular}{|c|c|c|c|c|}
\hline & & \multicolumn{2}{|c|}{ Type of School } & \multirow{2}{*}{ Total } \\
\hline & & Private & Government & \\
\hline \multirow{4}{*}{$\begin{array}{l}\text { During the past } 30 \text { days (one month), on the days you smoked, } \\
\text { how many cigarettes did you usually smoke? }\end{array}$} & $\begin{array}{c}\text { I did not smoke cigarettes during } \\
\text { the past } 30 \text { days }\end{array}$ & $85.5 \%$ & $93.7 \%$ & $89.7 \%$ \\
\hline & Less than 1 cigarette per day & $6.3 \%$ & $6.3 \%$ & $6.3 \%$ \\
\hline & 1 cigarette per day & $6.6 \%$ & & $3.2 \%$ \\
\hline & 2 to 5 cigarettes per day. & $1.7 \%$ & & $.8 \%$ \\
\hline \multicolumn{2}{|l|}{ Total } & $100.0 \%$ & $100.0 \%$ & $100.0 \%$ \\
\hline
\end{tabular}

Maximum percentage of students in both the schools did not smoke cigarettes in the past 30 days [private $(85.5 \%)$; Government (93.7\%). Similar percentage $(6.3 \%)$ of the students smoked less than 1 cigarette in both private and government school. $1.7 \%$ of the adolescent students in private school smoked more than 2-5 cigarettes per day. 
Table 5: Comparison of brand of cigarettes smoked between private and government school adolescent students in the past 30 days.

\begin{tabular}{|c|c|c|c|c|}
\hline & \multicolumn{2}{|c|}{ Type of School } & \multirow{2}{*}{ Total } \\
\hline & & Private & Government & \\
\hline \multirow{6}{*}{$\begin{array}{c}\text { During the past } 30 \text { days (one month), what brand of cigarette } \\
\text { did you usually smoke? }\end{array}$} & $\begin{array}{l}\text { I did not smoke cigarette during the } \\
\text { past } 30 \text { days }\end{array}$ & $92.1 \%$ & $88.6 \%$ & $90.3 \%$ \\
\hline & No usual brand & $1.0 \%$ & $4.4 \%$ & $2.7 \%$ \\
\hline & Wills & $3.6 \%$ & $2.2 \%$ & $2.9 \%$ \\
\hline & Gold Flake & & $4.7 \%$ & $2.4 \%$ \\
\hline & Charms & $2.3 \%$ & & $1.1 \%$ \\
\hline & Charminar & $1.0 \%$ & & $.5 \%$ \\
\hline \multicolumn{2}{|l|}{ Total } & $100.0 \%$ & $100.0 \%$ & $100.0 \%$ \\
\hline
\end{tabular}

Maximum percentage of students in both the schools did not smoke cigarettes in the past 30 days [private $(85.5 \%)$; Government (93.7\%). Adolescent students from government schools preferred Gold flake while adolescent students from private schools preferred Wills, Charms and Charminar brand of cigarettes.

Table 6: Influence of age on the access to cigarettes between private and government school adolescent students in the past 30 days.

\begin{tabular}{|c|c|c|c|c|}
\hline & & \multicolumn{2}{|c|}{ Type of School } & \multirow[b]{2}{*}{ Total } \\
\hline & & Private & Government & \\
\hline \multirow{3}{*}{$\begin{array}{l}\text { During the past } \\
30 \text { days (one } \\
\text { month), did } \\
\text { anyone ever } \\
\text { refuse to sell } \\
\text { you cigarettes } \\
\text { because of your } \\
\text { age? }\end{array}$} & $\begin{array}{l}\text { I did not thy to buy } \\
\text { cigarettes during the past } \\
30 \text { days (one month). }\end{array}$ & $\begin{array}{r}241 \\
79.5 \%\end{array}$ & $\begin{array}{r}269 \\
84.9 \%\end{array}$ & $\begin{array}{r}510 \\
82.3 \%\end{array}$ \\
\hline & $\begin{array}{l}\text { Yes, someone refused to } \\
\text { sell me cigarettes } \\
\text { because of my age. }\end{array}$ & $7.3 \%$ & $\begin{array}{r}23 \\
7.3 \%\end{array}$ & $\begin{array}{r}45 \\
7.3 \%\end{array}$ \\
\hline & $\begin{array}{l}\text { No, my age did not } \\
\text { prevent me from buying }\end{array}$ & $\begin{array}{r}40 \\
13.2 \% \\
\end{array}$ & $\begin{array}{r}25 \\
7.9 \%\end{array}$ & $\begin{array}{r}65 \\
10.5 \%\end{array}$ \\
\hline \multicolumn{2}{|l|}{ Total } & $\begin{array}{r}303 \\
100.0 \%\end{array}$ & $\begin{array}{r}317 \\
100.0 \%\end{array}$ & $\begin{array}{r}620 \\
100.0 \%\end{array}$ \\
\hline
\end{tabular}

Same percentage $(7.3 \%)$ of students from private and government schools were refused to sell those cigarettes because of their age. $13.2 \%$ of adolescent students from private schools were able to buy cigarettes with age not being a hindrance for them to buy cigarettes. This percentage $(7.9 \%)$ was lower in adolescents from Government schools. $10.5 \%$ of the students overall could buy cigarettes in spite of their age while $7.3 \%$ of the students could not buy cigarettes due to their age overall.

Table 7: Comparison of places of smoking between Private and Government adolescent students

\begin{tabular}{|c|c|c|c|c|}
\hline \multicolumn{2}{|c|}{} & \multicolumn{2}{c|}{ Type of School } & Total \\
\hline \multicolumn{2}{|c|}{} & Private & Government & \\
\hline Where do you usually smoke? & I have never smoked & $85.1 \%$ & $93.4 \%$ & $89.4 \%$ \\
\hline & At home & & $1.9 \%$ & $1.0 \%$ \\
\hline & At school & $1.9 \%$ & $1.0 \%$ \\
\hline & At work & $1.0 \%$ & $.7 \%$ & \\
\hline & At friends' houses & $.8 \%$ & \\
\hline & In public spaces (e.g. parks, shopping centres, street corners) & $7.6 \%$ & $3.7 \%$ \\
\hline & Other & $4.6 \%$ & $2.8 \%$ & $3.7 \%$ \\
\hline & & $100.0 \%$ & $100.0 \%$ & $100.0 \%$ \\
\hline
\end{tabular}

Government students prefer to smoke their cigarettes at home $(1.9 \%)$ and school $(1.9 \%)$ while private school students prefer to smoke at public spaces $(7.6 \%)$ and at friends 'houses $(1.7 \%)$.

Table 8: Comparison of tobacco use among parents of students in Private and Government schools

\begin{tabular}{|c|c|c|c|c|}
\hline & & \multicolumn{2}{|c|}{ Type of School } & \multirow[b]{2}{*}{ Total } \\
\hline & & Private & Government & \\
\hline \multirow{4}{*}{ Do your parents smoke, chew or apply tobacco? } & None. & $35.0 \%$ & $34.7 \%$ & $34.8 \%$ \\
\hline & Both & $4.6 \%$ & $2.5 \%$ & $3.5 \%$ \\
\hline & Father only & $56.1 \%$ & $57.1 \%$ & $56.6 \%$ \\
\hline & I don't know & $4.3 \%$ & $5.7 \%$ & $5.0 \%$ \\
\hline \multicolumn{2}{|l|}{ Total } & $100.0 \%$ & $100.0 \%$ & $100.0 \%$ \\
\hline
\end{tabular}


Tobacco use among parents of students did not influence the habit of tobacco use in both private and government school. There is a higher percentage of tobacco use among both parents of students in private school $(4.6 \%)$ than when compared with parents of students in government school $(2.5 \%)$. There is a higher percentage of tobacco use among fathers of students in Government school (57.1\%) than when compared with fathers of students in Private school $(56.1 \%)$.

\section{Discussion}

This study aims to determine the magnitude of tobacco use (both smoked and smokeless tobacco products) among adolescent high-school students in Visakhapatnam, sub metropolitan city in Andhra Pradesh. The study also aims to identify the factors that influence their decisions about whether to initiate tobacco use. The study adopted a true experimental design. Random sampling is applied for the study. Schools with at least 100 secondary students (in grades 8,9 and 10) are considered for the study. Eligible schools were stratified into governmental and nongovernmental categories. More than $50 \%$ of schools were selected on the basis of Probability Proportional to Enrolment size (PPE), i.e. the schools with high number of students are more likely to be selected than schools with low number of students. Students are selected from a Private and a Government school in the city of Vishakhapatnam and a total number of 620 students, out of which 304 are from Private school and 316 are from government school.

\section{Prevalence}

$51.8 \%$ of the students were using tobacco in Private school as compared to $40.1 \%$ of the students in Government school.

$5 \%$ of the students in the Private school are using tobacco in the form of bidis and 5.6\% in the form of cigarettes; $16.5 \%$ of the students are smoking tobacco in other forms in comparison with none of the students using bidis and cigarettes in government school while $11 \%$ of the students are smoking tobacco in other forms by students of government school.

$10.3 \%$ of the students are $8-9$ years old when they first tried tobacco and $10 \%$ of the students are 12-13 years old when they tried tobacco followed by students of 10-11 years old.

\section{Knowledge and Attitudes}

In the present study, $49.2 \%$ think boys and $20.8 \%$ think girls who smoke look more attractive. There is no difference in the attitude with regards to attractiveness of the boys who smoke in both Private and Government school.

Adolescent students from Government school (65.9\%) thought that smoking or chewing tobacco makes girls look less attractive more than when compared with Private school (58.4\%).

$20.8 \%$ students from Private school and $13.2 \%$ from Government school felt that there is no difference in attractiveness between smokers and non smokers.

In the present study $24.4 \%$ think boys and $12.2 \%$ think girls who smoke have more friends. $33.4 \%$ of the students from Government school think boys who smoke or chew tobacco have more friends.

$69 \%$ of the students from Private school think boys who smoke or chew tobacco have fewer friends.
$11.70 \%$ of the students from Government school and $16.2 \%$ of the students from Private school think that there will be no difference in the number of friends between smokers and non smokers.

Gajalaxmi et al. (2004). $24.0 \%$ think boys and $13.4 \%$ think girls who smoke have more friends $21.1 \%$ think boys and $15.6 \%$ think girls who smoke look more attractive. ${ }^{[7]}$

\section{Access and Availability - Current Smokers}

In the present study $1 \%$ of the students usually smoke at home $3.7 \%$ of the students prefer public spaces.

This indicates that students are more comfortable to smoke at public spaces than at home.

Government students prefer to smoke their cigarettes at home $(1.9 \%)$ and school $(1.9 \%)$ while private school students prefer to smoke at public spaces $(7.6 \%)$ and at friends 'houses $(1.7 \%)$.

$10.8 \%$ of the students buy cigarettes from a store. $8.60 \%$ of the students from private school and $12.90 \%$ of the students from government school bought cigarette/tobacco products from a street vendor. This indicates government school adolescent students buy from a street vendor more than private school adolescent students. $70.6 \%$ of the students from private school and $77.30 \%$ of the students from government school did not use any tobacco product during the past 30 days.

$8.30 \%$ of the students from private school borrowed them from someone else. There is no significant difference between male and female regarding access to or regarding access to or availability of smoking and smokeless tobacco.

1 in 5 current smokers and one in three current smokeless tobacco users smoke and chew/apply tobacco, respectively, at home. Among current tobacco users 54\% purchase tobacco products in a storeand similar percentage bought tobacco in a store where they were NOT refused purchase because of their age ${ }^{\text {[6-11] }}$

\section{Conclusion}

Tobacco use is more prevalent among adolescents and several factors influence their decisions to initiate at that age. This study is supported to prove that the magnitude of tobacco use is very high and several factors contribute to the initiation of tobacco use during adolescence.

\section{Acknowledgment}

The author is thankful to Department of Psychiatry for providing all the facilities to carry out this work.

\section{Conflict of Interest: None}

\section{Financial Support: Nil}

\section{References}

1. Marilyn JH, David W. Wonges essential of pediatric nursing.8th edition. India: Reed Elsevier India (p) Ltd, 2009.

2. Frank B, Joseph TD, Michael J. Health Risks Associated With Cigar Smoking, India. JAMA. 2000;284(18):320-1.

3. Jindal SK et al. Tobacco smoking in India prevalence, quit-rates and respiratory morbidity. National Med J India. 2003;48(2):37-42.

4. Sinha DN, Rahul R. Linking Global Youth Tobacco Survey (GYTS) data to the WHO framework 
convention on tobacco control: the case for India. Indian J Public Health 2006;50(6):76-89.

5. Connie HY, Margaret HF, Michelle G. Cancer nusing principle and practice.6th edition. London: Jones and Bartlett publishers (p) Ltd, 2005.

6. Bauman KE, Koch GG. Validity of self-reports and descriptive and analytical conclusions: The case of cigarette smoking by adolescents and their mothers. American Journal of Epidemiology 1983;118(1):90-98.

7. Vendhan Gajalakshmi, Samira Asma, Charles Warren. Tobacco Survey among Youth in South India. Asian Pacific J Cancer Prev 2004;5:273-278.

8. Young M, Denny G, Donnelly J, Rodriguez M, Hawkins M. Area specific self-esteem and sexual behavior among Hispanic middle school students. American Journal of Health Education 2002;33(6):34449.

9. Morello P, Duggan A, Adger H, Anthony JC, Joffe A. Tobacco use among high school students in Buenos Aires, Argentina. American Journal of Public Health 2001;91(2):219-25.

10. Brown SL, Teufel JL, Birch DA, Izenberg N, Lyness D. Perceptions of tobacco use in early adolescents.J Prim Prev 2006;27(5):515-26.

11. Mazanov J, Byrne DG. A comparison of predictors of the adolescent intention to smoke with adolescent current smoking using discriminant function analysis. British Journal of Health Psychology 2002;7:185-204. 